
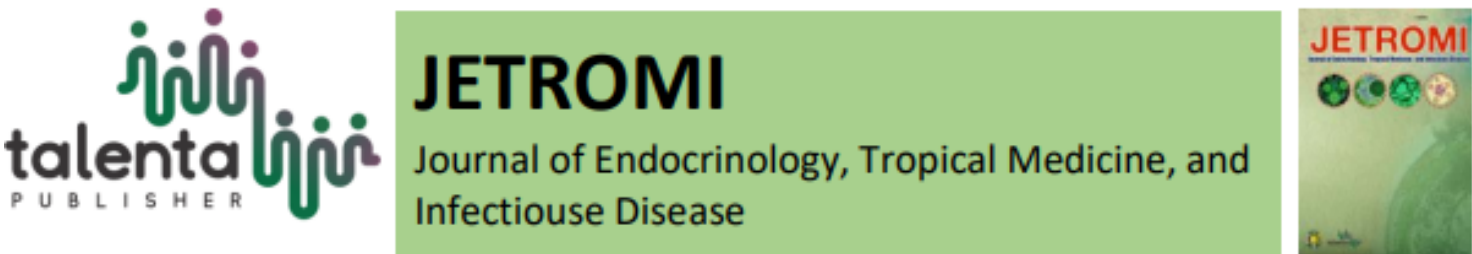

\title{
Correlation Between Platelet Distribution Width and Troponin I in Acute Myocardial Infarction
}

\author{
Maulinda Putri*, Refli Hasan, Rahmad Isnanta \\ Division of Cardiology of Department of Internal Medicine. Faculty of Medicine, Universitas Sumatera \\ Utara
}

\begin{abstract}
Background. Coronary artery disease (CAD) is caused by narrowing of the coronary arteries. In the event of acute myocardial infarction (AMI), there will be an increase in heart markers. Several studies have examined the relationship between Platelet Distribution Width (PDW) and AMI, but there is no specific correlation with troponin as the most sensitive and specific cardiac biomarker for AMI. This study aims to see the correlation PDW values with troponin I in patients with AMI. Method. This study was a crosssectional method to determine the correlation of PDW variable values with troponin I in patients with AMI. In this study, the sample consisted of 64 people. Results. There is a moderate correlation between PDW and troponin $\mathrm{I}(\mathrm{r} 2=0.72, \mathrm{p}<0.001)$. There is a strong correlation with positive direction between PDW and Troponin I in patients with AMI based on the onset of chest pain $(<6$ hours and $>6$ hours : $\mathrm{r} 2=0.647 \mathrm{p}<0.001$ and $\mathrm{r} 2=$ $0.756, \mathrm{p}<0.001$ ). Conclusion. Platelet Distribution Width (PDW) is strongly correlated with Troponin I in patients with AMI, and based on chest pain onset also has a significantly positive correlation.
\end{abstract}

Keywords: CAD, AMI, Troponin I, PDW

Abstrak. Latar belakang. Penyakit jantung koroner (PJK) adalah penyakit jantung yang disebabkan oleh penyempitan arteri koronaria. Pada kejadian infark miokard akut (IMA) terjadi peningkatan penanda jantung. Beberapa penelitian sudah meneliti hubungan Platelet Distribution Width (PDW) dengan IMA, namun tidak menentukan korelasi troponin sebagai penanda jantung yang paling sensitif dan spesifik terhadap IMA. Penelitian ini bertujuan menentukan korelasi nilai PDW dengan troponin I pada pasien IMA. Metode. Penelitian ini berdesain potong lintang untuk menentukan korelasi nilai variabel PDW dengan troponin I pada pasien IMA. Penelitian ini mengikutsertakan sampel yang terdiri dari 64 orang. Hasil. Terdapat korelasi kuat dengan arah positif antara PDW dengan troponin I pada pasien IMA. Terdapat korelasi kuat dengan arah positif antara PDW dengan Troponin I pada pasien IMA berdasarkan onset nyeri dada $(<6$ jam : $r 2=0,647, p<0.001$ dan $>6$ jam $r 2=0,756, p<$ 0.001 ). Kesimpulan. PDW berkorelasi kuat dengan Troponin I pada pasien dengan IMA, dan berdasarkan onset nyeri dada memiliki arah korelasi yang positif.

Kata Kunci: $C A D, A M I$, Troponin I, PDW

Received 30 June 2020 | Revised 24 August 2020 | Accepted 28 August 2020

\footnotetext{
${ }^{*}$ Corresponding author at: Division of Cardiology of Department of Internal Medicine. Faculty of Medicine, Universitas Sumatera Utara

E-mail address: maulindaputri2110@yahoo.com
} 


\section{Introduction}

Coronary artery disease (CAD) is caused by narrowing of the coronary arteries due to atherosclerosis or spasm or a combination of both. World Health Organization (WHO) in 2017 estimated 17.9 million people died of heart disease, representing $31 \%$ of all global deaths [1]. In Indonesia, the basic health research data in 2018 showed that 15 out of 1,000 Indonesians suffer from coronary heart disease [2].

Acute coronary syndrome (ACS) is a collection of symptoms that arise due to acute myocardial ischemia [3]. In the event of acute myocardial infarction (AMI), there will be an increase in heart markers. Troponin I/T has higher sensitivity and specificity than CK-MB. Troponin $\mathrm{T}$ and troponin I provide balanced information on myocyte necrosis. Troponin-I has a higher specificity than troponin $\mathrm{T}$ in renal dysfunction [4].

Platelet activation and aggregation play an important role in the pathophysiology of CAD [5]. Platelet Distribution Width (PDW) is an important and simple marker that increases significantly during platelet activation. PDW shows varying platelet sizes. Large PDW in patients with AMI occur because they are caused by an increase in bone marrow activity during thrombocytopoiesis [6].

Mappagara et al in 2016 did a research with a value of $\mathrm{r}$ 0.552, shows that an increase in PDW can predict more severe disease in ACS, especially IMA-EST which affects several heart blood vessels. However, there was no specific correlation with troponin as the most sensitive and specific cardiac biomarker for AMI. This study aims to determine the correlation of PDW with troponin I levels in patients with acute myocardial infarction.

\section{Methods}

This is a retrospective cross-sectional study, was conducted at the H. Adam Malik General Hospital in Medan in January 2020 using medical record data in January-December 2019. The inclusion criteria includes: (1) All patients who have been diagnosed with AMI in medical records in this case either with or without ST elevation ECG, (2) patients whose medical records contain information on the value of PDW. Meanwhile, the exclusion criteria includes (1) incomplete medical record data, (2) patients with heart disease other than AMI, (3) patients with active autoimmune disease, inflammatory disease, and active infection, (4) history of blood transfusions, (5) patients with hematologic disorders that directly affect platelet size and volume, (6) patients with end-stage renal disease undergoing hemodialysis, and (7) patients with malignancy. Univariate analysis is used to determine the demographic characteristics of this study. Data analysis was then performed on the correlation of the independent variable PDW) with the dependent variable (Troponin I) using the Pearson correlation test. 


\section{Results}

From the overall medical record data of AMI patients seeking treatment at $\mathrm{H}$. Adam Malik General Hospital Medan in the January-December 2019, 64 samples were found that met the inclusion criteria. The characteristics of respondents are listed in the table 1 .

Table 1. Demographic and Biochemical Characteristics of Respondents in AMI

\begin{tabular}{|c|c|}
\hline Variable & $N=64$ \\
\hline Male, n (\%) & $57(89,1 \%)$ \\
\hline Age, years $(\mathrm{X} \pm \mathrm{SD})$ & $55.02 \pm 11.02$ \\
\hline Hypertension & $39(60.9 \%)$ \\
\hline Diabetes Mellitus & $37(57.8 \%)$ \\
\hline Smoking & $51(79.7 \%)$ \\
\hline Dyslipidemia & $36(56.3 \%)$ \\
\hline $\mathrm{BMI}<25$ & $28(43.8 \%)$ \\
\hline AMI-EST & $48(75 \%)$ \\
\hline $\mathrm{Hb}, \mathrm{g} / \mathrm{dL}$ & $14.3(9.8-17.5)$ \\
\hline Leukocytes, cells/mL & $10.106(6.670-10.980)$ \\
\hline Platelet, cells $/ \mathrm{mL}$ & $240.500(156.000-448.000)$ \\
\hline PDW & $13.3 \pm 3.04$ \\
\hline Troponin I, ng/mL & $4.84(0.58-30.3)$ \\
\hline Creatinin, mg/dL & $0.81(0.45-1.30)$ \\
\hline Blood glucose level, mg/dL & $154(84-293)$ \\
\hline
\end{tabular}

Based on the 64 samples above, the researchers divided 32 study samples for each group divided according to the onset of chest pain that is $<6$ hours and $>6$ hours. The characteristics of the two groups can be seen in the table 2 .

Table 2. Demographic and Biochemical Characteristics of Respondents Based on Chest Pain Onset

\begin{tabular}{lcc}
\hline & \multicolumn{2}{c}{ Onset of Chest Pain } \\
\cline { 2 - 3 } Characteristics & $<\mathbf{6}$ hours $(\mathbf{N = 3 2})$ & $>\mathbf{6}$ hours $(\mathbf{N = 3 2})$ \\
\cline { 2 - 3 } Male & $27(84 \%)$ & $30(93.8 \%)$ \\
Age (Mean \pm SD) & $56.56 \pm 11.05$ & $53.47 \pm 10.41$ \\
Hypertension & $18(56.3 \%)$ & $21(65.6 \%)$ \\
Diabetes Mellitus & $19(59.4 \%)$ & $18(56.3 \%)$ \\
Smoking & $27(84.4 \%)$ & $26(81.3 \%)$ \\
Dyslipidemia & $17(53.1 \%)$ & $19(59.4 \%)$ \\
BMI & $28(43.8 \%)$ & $13(40.6 \%)$ \\
AMI-EST & $16(50 \%)$ & $24(75 \%)$ \\
Hb, g/dL & $14.55(9.8-17)$ & $13.9(4.94-19.8)$ \\
Leukocytes, cells/mL & $10.015(6.670-10.980)$ & $10.305(6950-11.090)$ \\
Platelet, cells/mL & $245.656 \pm 56.778$ & $256.178 \pm 67.574$ \\
PDW & $12.13 \pm 1.33$ & $14.59 \pm 3.72$ \\
Troponin I, ng/mL & $2.04 \pm 1.04$ & $18.3 \pm 7.78$ \\
Creatinin, mg/dL & $0.81(0.45-1.29)$ & $0.82(0.56-1.30)$ \\
Blood glucose level, mg/dL & $173 \pm 61.4$ & $167 \pm 59.8$ \\
& & \\
\hline
\end{tabular}

There was a significant correlation with the positive direction between PDW and troponin I in patients with AMI. With a p-value $<0.001$ and a $\mathrm{r} 2: 0.713$. This shows that the higher the PDW value, the higher the Troponin I level in patients with AMI. 


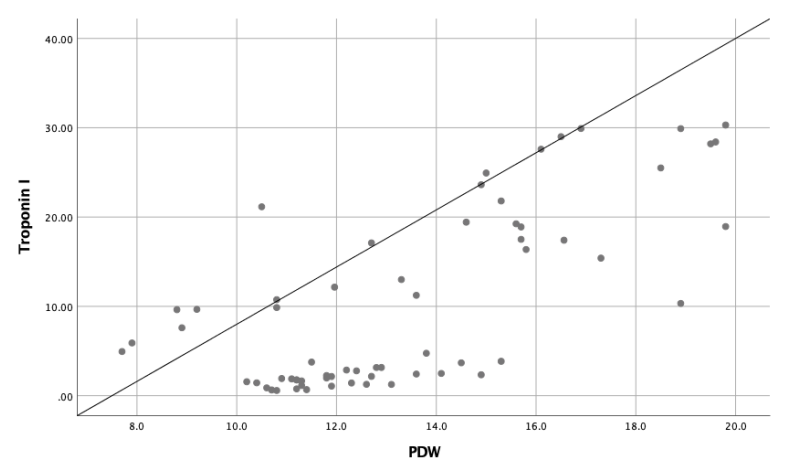

Figure 1. Scatter plot correlation between PDW and Troponin $I(r 2=0.713, p<0.001)$ in patients with AMI.

In this study, the Pearson test was conducted to find the correlation between PDW and Troponin I in 32 samples of each group. The results show that there is a significant correlation with the positive direction between PDW and Troponin I in patients with AMI based on the onset of chest pain.

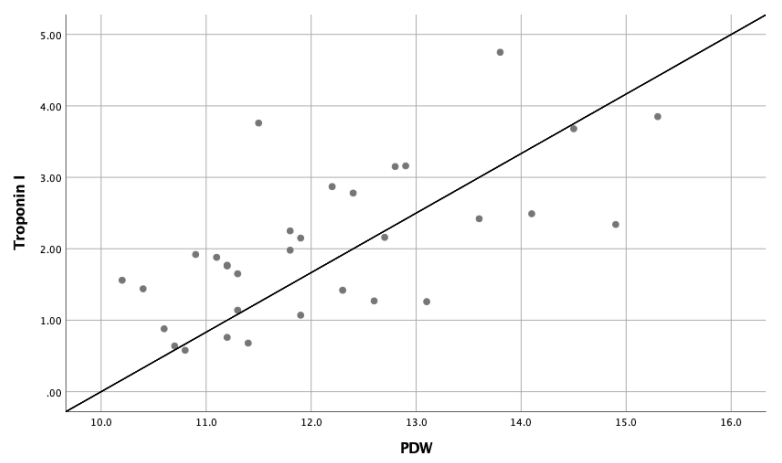

Figure 2. Scatter Plot correlation of PDW with Troponin I based on Chest Pain Onset $<6$ hours $(\mathrm{r} 2=0.647, \mathrm{p}<0.001)$ in patients with AMI.

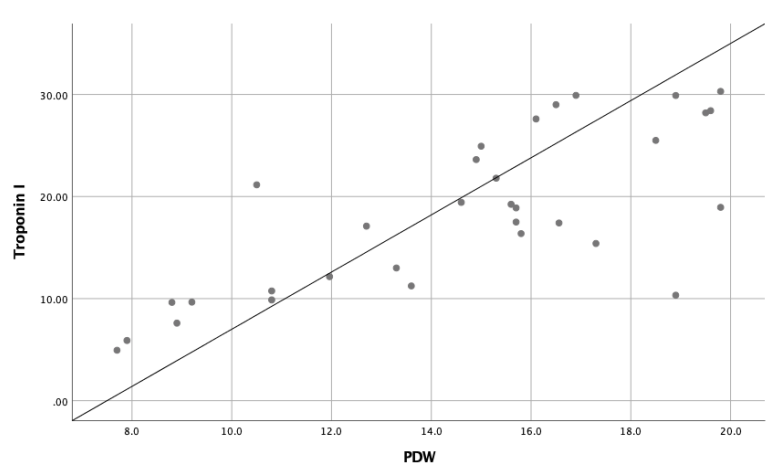

Figure 3. Scatter Plot correlation of PDW with Troponin I based on Chest Pain Onset $>6$ hours $(\mathrm{r} 2=0.756, \mathrm{p}<0.001)$ in patients with AMI. 


\section{Discussion}

In this study, AMI was found more in males $(89.1 \%)$, both in the onset of chest pain $<6$ hours and $>6$ hours $(84.4 \%$; 93.8\%). This result, accordance with previous studies in Padang (2017) and Medan (2018), found that the prevalence of AMI was higher in males $(70.8 \% ; 87.4 \%)[7,8]$. This is caused by the oestrogen in females who have a protective effect on endothelial blood vessels, that release nitric oxide which can cause vasodilation, regulation of prostaglandin production, and inhibition of smooth muscle proliferation [9]. Other risk factors that can also influence smoking are generally more common in males than females [10].

In this study, the mean age of patients suffering from AMI was $55.02( \pm 11.02)$ years and the average age of patients who had onset of chest pain <6 hours was $56.56(11,570)$ years and patients who had onset of chest pain $>6$ hours was $53,47(10,411)$ years old. This result is also in accordance with previous studies in Padang (2017) which the mean age of AMI was 56.75 (9.34) [7]. The incidence of AMI increases with age, which is associated with an increase in risk factors such as hypertension, diabetes mellitus, dyslipidemia [11].

Based on risk factors, it was found that hypertension patients are higher than patients without hypertension $(60.9 \%$ vs $39 \%)$, both in the onset of chest pain <6 hours and >6 hours $(56.3 \%$; $65.6 \%$ ). Increased blood pressure is a heavy burden for the heart, causing left ventricular hypertrophy. High and persistent blood pressure will also cause direct trauma to the walls of coronary arteries, making it easier for atherosclerosis to occur. The more severe the hypertension condition suffered, the greater the risk of developing CAD.

Patient with DM is higher than those without DM (57.8\% vs $42.2 \%)$, both in respondents with DM in the onset of chest pain $<6$ hours and $>6$ hours $(59.4 \%$; $56.3 \%)$. DM is one of the main factors for coronary artery disease factors and more than $40 \%$ of patients with ACS has DM [15]. This is caused by endothelial dysfunction, abnormal platelet activity and impaired balance of coagulation-fibrinolysis [16]. Platelet activation is one of the key mechanisms underlying atherothrombosis in AMI, where platelets in diabetic patients experience dysregulation of several signaling pathways, which leads to increased platelet reactivity [17].

Patients who smokes are also higher than patients who didn't (79.7\% vs $20.3 \%)$, both in the onset of chest pain $<6$ hours and $>6$ hours $(84.4 \% ; 81.3 \%)$. Research in Makassar (2016) found patients with AMI with smoking risk factors as $76.12 \%$ [12]. The most traditional risk factor for AMI patients in the study by Amaliah R et al in 2017 was smoking (41.7\%). Smoking increases the effects of other risk factors, such as increasing the incidence of hyperlipidemia, hypertension, and diabetes mellitus, which both increase the incidence of CAD. Smoking can cause inflammation of blood vessels which results in narrowing of the arteries, reducing blood flow and oxygen supply to organs include heart, which can cause myocardial infarction. 
From the results of this study, patient with dyslipidemia is higher than patients without dyslipidemia (56.3\% vs $43.8 \%$ ), both in the onset of chest pain $<6$ hours and $>6$ hours $(53.1 \%$; $59.4 \%$ ). This result is in accordance with previous studies. In a study in Kuningan (2014), they found 56 patients with AMI with dyslipidemia (78.8\%) [14]. This case of dyslipidemia can simply be a risk factor for AMI because in the process of disruption of the lipid profile in the blood there is an accumulation of fat in the lining of blood vessels which ultimately reduces the diameter of the blood vessel lumen resulting from ischemia with the subsequent manifestation of infarction. Abnormalities in lipid profiles are a factor of atherosclerosis.

The results of this study also found that patients who had a BMI $>25$ are higher than patients with a BMI <25 (56.3\% vs $43.8 \%)$, both in the onset of chest pain <6 hours and >6 hours $(53.1 \%$; $59.4 \%$ ). High BMI is an independent risk factor for an increased incidence of myocardial infarction and ischemic heart disease [18]. Obesity is associated with a higher incidence of metabolic syndrome components, which significantly increases the risk of CAD [19].

In this study, patient was divided into two groups, AMI with ST-elevation and without ST elevation. The group of patients with ST-elevation was higher than those without ST elevation (62.5\% vs $37.5 \%)$, both in the onset of chest pain $<6$ hours and $>6$ hours $(50 \% ; 75 \%)$. These results are consistent with the study of Bacci et al in Sri Lanka who found the prevalence of STEMI patients to be greater than NSTEMI and UAP patients (57.2\%; 22.1\% and 20.6\%) [20]. Research in Indonesia shows the same results, with a ratio of $61 \%$ and $39 \%$ [21]. This can be caused by the lack of prevention efforts on several risk factors in previous health facilities so that the number of AMI patients with ST-elevation is high [20].

In this study, the results showed that there was a significant correlation between PDW and Troponin I in patients with acute myocardial infarction $(\mathrm{r} 2=0.713, \mathrm{p}<0.001)$. This shows that the higher the PDW value, the higher the Troponin I level in patients with acute myocardial infarction. And based on the onset of chest pain turned out to have a significant correlation also between PDW with troponin I with the correlation value of each group onset of chest pain $<6$ hours $(\mathrm{r} 2=0.647, \mathrm{p}<0.001)$ and the onset of chest pain $>6$ hours $(\mathrm{r} 2=0.756, \mathrm{p}<0.001)$.

Until now there has been no research that directly assesses the correlation between PDW and Troponin I according to the onset of chest pain experienced by patients. Research by Reddy et al regarding changes in platelet volume in STEMI patients comparing the STEMI group with the control group found that the PDW value was significantly higher statistically in the group with STEMI compared to the control group $((17.8 \pm 2.2$ vs $16.3 \pm 0.7))$ with a value $\mathrm{p}<0.001$. In the study, there was no direct statistical test between PDW and Troponin I, but the diagnosis of STEMI was adjusted according to the criteria of The Third Universal Definition of Myocardial Infarction, namely an increase in cardiac biomarkers that was very sensitive and specific, namely cardiac troponin-I accompanied by one of the symptoms of ischemia, changes in the description 
of the picture electrocardiography, changes in imaging features and/or identification of intracoronary thrombus on angiographic examination or autopsy [22].

Other studies in Sri Lanka (2018) regarding the relationship between platelet volume parameters and STEMI also found a statistically significant relationship between PDW levels with a cut off of $15.55 \mathrm{fL}$ and the occurrence of STEMI $(\mathrm{p}=0.000)$ and a positive correlation $(\mathrm{r}=0.556)$, but in this study, the diagnosis of STEMI was not specifically described ACS through the examination of troponin I levels [5]. PDW reflects variance in platelet size due to the release of activated platelets. This shows the heterogeneity of platelet size by providing the relative width of PDW on volume [5]. The most common cause of coronary thrombosis is plaque rupture, which allows platelet contact with a very thrombogenic necrotic nucleus. Metabolically larger and enzymatic platelets are more active than smaller ones. Larger platelets contain more prothrombotic material, release thromboxane-A2 increase per unit volume, and show larger glycoprotein IIb-IIIa receptors. PDW increases significantly in patients with STEMI and is an independent predictor of acute STEMI [23].

Troponin is one of the most sensitive and specific biomarkers for detecting damage to the heart muscles. Under normal circumstances, there is no troponin $\mathrm{T}$ and troponin $\mathrm{I}$ in circulation. Troponin will be released into the circulation when necrosis of the heart muscles is an indicator of damage to the heart muscles [24]. Increased levels of cardiac troponin begin at the onset of myocardial infarction for 2-3 hours and almost $100 \%$ increase in troponin levels in myocardial infarction for 6 hours until a peak of 24 hours and troponin levels will continue to show increased results up to 1-2 weeks [25].

Limitations in this study were not conducted assessments of outcome outcomes and mortality in the two AMI groups with the onset of chest pain $<6$ hours and AMI with the onset of chest pain $>6$ hours so that the average PDW values found in this study cannot be used to determine the prognosis in both groups.

\section{Conclusion}

Platelet Distribution Width of PDW is strongly correlated with Troponin I in patients with AMI, and based on chest pain onset also has a significantly positive correlation.

\section{REFERENCES}

[1] "Cardiovascular diseases (CVDs)," World Health Organization. [Online]. Available: http://www.who.int/mediacentre/factsheets/fs317/en/. [Accessed: 22-Oct-2019].

[2] “Laporan Hasil Riset Kesehatan Dasar (Riskesdas)," Badan Litbangkes, 2018 [Online]. Available: https://www.litbang.kemkes.go.id/laporan-riset-kesehatan-dasar-riskesdas/. 
[3] G. R. Muhammad, P. Ardhianto. "Profil Faktor Risiko Atherosklerosis Pada Kejadian Infark Miokard Akut Dengan St-Segment Elevasi Di Rsup Dr Kariadi Semarang", Jurnal Kedokteran Diponegoro, vol. 4, no.4, pp.849-858. 2015.

[4] Perhimpunan Dokter Spesialis Kardiovaskular Indonesia. "Pedoman Tatalaksana Sindrom Koroner Akut."edisi keempat, pp. 9. 2018

[5] B. Y. Alvitigala, M. A. F. Azra, D. U. Kottahachchi, M. M. P. T. Jayasekera, and R. A. N. K. Wijesinghe, "A study of association between platelet volume indices and ST elevation myocardial infarction," IJC Heart \& Vasculature, vol. 21, pp. 7-10, 2018.

[6] A. Bekler, M. T. A. Ozkan, E. Tenekecioglu, E. Gazi, A. U. Yener, A. Temiz, et al."Increased Platelet Distribution Width Is Associated With Severity of Coronary Artery Disease in Patients With Acute Coronary Syndrome," Angiology, vol. 66, no. 7, pp. 638-643, 2014.

[7] R. Amaliah, R. Yaswir, and T. Prihandani, "Gambaran Homosistein pada Pasien Infark Miokard Akut di RSUP Dr. M. Djamil Padang,” Jurnal Kesehatan Andalas, vol. 8, no. 2, p. 351, 2019.

[8] Henny. "Hubungan Indeks Massa Tubuh ( BMI ) dengan Infark Miokard Akut Elevasi Segmen St ( AMIest ) di RSUP Haji Adam Malik Periode Januari-Desember 2018". 2018

[9] L. S. Mehta, T. M. Beckie, H. A. Devon, C. L. Grines, H. M. Krumholz, M. N. Johnson,. et al.“Acute Myocardial Infarction in Women," Circulation, vol. 133, no. 9, pp. 916947, 2016.

[10] C. Campbell, A. Bailey, M. Rains, and C. Laney, "Biomarkers of acute myocardial infarction in the elderly: troponin and beyond," Clinical Interventions in Aging, p. 1081, 2014.

[11] W. S. Aronow, "Myocardial Infarction in the Elderly," Drug Safety, vol. 25, no. 11, pp. 753-758, 2002.

[12] I. Mappangara, A. A. Mappahya, and S. Witjaksono, "The Comparative and Usefulness of Platelet Distribution Width in Acute Coronary Syndrome," The Indonesian Biomedical Journal, vol. 8, no. 3, p. 173, 2016. https://doi.org/10.18585/inabj.v8i3.219

[13] S. Putra, E. F. Elfi, and A. Afdal, "Gambaran Faktor Risiko dan Manajemen Reperfusi Pasien IMA-EST di Bangsal Jantung RSUP Dr. M. Djamil Padang,” Jurnal Kesehatan Andalas, vol. 6, no. 3, p. 621, 2018.

[14] B. Budiman, R. Sihombing, and P. Pradina, "Hubungan Dislipidemia, Hipertensi Dan Diabetes Melitus Dengan Kejadian Infark Miokard Akut," Jurnal Kesehatan Masyarakat Andalas, vol. 10, no. 1, p. $\quad 32, \quad 2017$. https://doi.org/10.24893/jkma.v10i1.160

[15] S. G. Foussas, “Acute coronary syndromes and diabetes mellitus,” Hellenic Journal of Cardiology, vol. 57, no. 5, pp. 375-377, 2016. 
[16] J. Dąbek, M. Bałys, M. Majewski, and Z. Gąsior, "Diabetic Patients with an Acute Myocardial Infarction in Terms of Risk Factors and Comorbidities Management: Characteristics of the Highest-Risk Individuals," Advances in Clinical and Experimental Medicine, vol. 25, no. 4, pp. 655-663, 2016.https://doi.org/10.17219/acem/58785

[17] B. Hudzik, J. Szkodziński, A. Lekston, M. Gierlotka, L. Poloński, and M. Gąsior, "Mean platelet volume-to-lymphocyte ratio: a novel marker of poor short- and long-term prognosis in patients with diabetes mellitus and acute myocardial infarction," Journal of Diabetes and its Complications, vol. 30, no. 6, pp. 1097-1102, 2016. https://doi.org/10.1016/j.jdiacomp.2016.04.010

[18] L. Wang, W. Liu, X. He, Y. Chen, J. Lu, K. Liu, et al. “Association of overweight and obesity with patient mortality after acute myocardial infarction: a meta-analysis of prospective studies," International Journal of Obesity, vol. 40, no. 2, pp. 220-228, 2015. https://doi.org/10.1038/ijo.2015.176

[19] S. H. Lee, M. H. Jeong, J. H. Kim, M. C. Kim, D. S. Sim, Y. J. Hong, et al, "Influence of obesity and metabolic syndrome on clinical outcomes of ST-segment elevation myocardial infarction in men undergoing primary percutaneous coronary intervention," Journal of Cardiology, vol. 72, no. 4, pp. 328-334, 2018. https://doi.org/10.1016/j.jjcc.2018.03.010

[20] M. R. Bacci, F. L. A. Fonseca, L. F. F. Nogueira, F. R. Bruniera, F. M. Ferreira, D. M. D. Barros, et al, "Predominance of STEMI and severity of coronary artery disease in a cohort of patients hospitalized with acute coronary syndrome: a report from $\mathrm{ABC}$ Medical School," Revista da Associação Médica Brasileira, vol. 61, no. 3, pp. 240-243, 2015.

[21] Nugroho, S. Irfan. "Perbedaan Kadar SGOT pada Pasien ST elevasi Miokard Infark (STEMI) dan Non-ST Elevasi Miokard Infarl (NSTEMI) di RSUD Dr. Moewardi," Jurnal Kedokteran Universitas Muhammadiya Surakarta, 2015.

[22] S. K. Reddy, "Significance of Platelet Volume Indices in STEMI Patients: A CaseControl Study," Journal of Clinical And Diagnostic Research, 2017.

[23] M. Cetin, E. M. Bakirci, E. Baysal, H. Tasolar, M. Balli, M. Cakici, et al, "Increased Platelet Distribution Width Is Associated With ST-Segment Elevation Myocardial Infarction and Thrombolysis Failure," Angiology, vol. 65, no. 8, pp. 737-743, 2014. https://doi.org/10.1177/000331971352006

[24] E. Braunwald, R. O. Bonow, D. L. Mann. "Acute Coronary Syndrome," Braunwald's Heart Diseases : A Textbook of Cardiovascular Medicine $9^{\text {th }}$ Edition. Philadephia, Elsevier Saunders, 2012.

[25] G. J. Murphy. Mayo Clinic Cardiology. 4th edition. New York: Oxford University Press, p. 609. 2010 